\title{
SAFETY OF INSECTICIDES TO HONEY BEES TARGETED FOR THE MANAGEMENT OF HELICOVERPA ARMIGERA IN PIGEON PEA
}

\author{
KAMBREKAR, D. N. ${ }^{1}-$ JAHAGIRDAR, S. ${ }^{2}$ \\ ${ }^{I}$ Department of Agricultural Entomology, University of Agricultural Sciences, Dharwad \\ 580005, Karnataka, India \\ ${ }^{2}$ Department of Plant Pathology, University of Agricultural Sciences, Dharwad 580005, \\ Karnataka, India \\ *Corresponding author \\ e-mail: kambrekardn@gmail.com \\ (Received $23^{\text {rd }}$ Sep 2020; accepted $19^{\text {th }}$ Jan 2021)
}

\begin{abstract}
The present study aimed to investigate the repellent proprieties of recommended insecticides targeted at the management of pigeon pea pod borer, Helicoverpa armigera along with the recuperation of three species of honey bees under field condition during 2018-19 and 2019-20 at Vijayapur and Bagalkot districts of Karnataka-India. The repellency studies of insecticides concerning honey bees in both locations and during both the years indicated that the recovery percentage of honey bees (Apis florea, Apis cerana and Apis dorsata) for the treated field had the fastest rate in the plots treated with Neem Seed Kernel Extract followed by chlorantraniliprole compared to other insecticides. Further, normal activity (100\% recovery) of the bees was realized in the treatment with Neem seed kernel extract and chlorantraniliprole which took only 2 and 3 days as compared to more than 7 days for other insecticides. Among the bee species studied, A. dorsata resumed its normal activity sooner than A. cerana and A. florea. A. florea was the most sensitive species to insecticides in pigeon pea. The results indicate the faster recovery of bees which has augmented pollination services and has a greater relevance in enhancing the yield in pigeon pea, whenever the insecticides with less repellent activity were used in the IPM programmes.
\end{abstract}

Keywords: chlorantraniliprole, Helicoverpa armigera, neem seed kernel extract, pollination

\section{Introduction}

Pigeon pea (Cajanus cajan (L.) Millsp.) is cultivated in tropical and sub-tropical areas and is an important legume crop of Asia (especially, the Indian subcontinent), Latin America and Eastern and Southern Africa. Globally, it is grown on around 5 million hectares ( $\mathrm{m} \mathrm{ha}$ ) in about 82 countries of the world. Pigeon pea has a significant place in Indian farming and India contributes $90 \%$ of the world pigeon pea production. It is the second most important pulse crop next to chickpea, covering an area of around $4.42 \mathrm{~m}$ ha (occupying about $14.5 \%$ of area under pulses) and production of $2.86 \mathrm{mt}$ (contributing to $16 \%$ of total pulse production) and productivity of about $707 \mathrm{~kg} / \mathrm{ha}$. It is staple diet throughout the country that is mainly consumed as dry split daal besides several other uses of various parts of pigeon pea plant. It is an excellent source of protein (20-22\%), supplementing energy rich cereal diets in a mainly vegetarian population. In addition to food, it is used as fodder, feed, and fuel and has functional utility for making baskets, huts, fences, etc.

Pollinators play an important role in providing key component of ecosystem services in the form of crop pollination that is vital to maintain the plant communities and to enhance the quality and quantity of agricultural produce. It has been estimated that one 
third of the food eaten by humans, either directly or indirectly, comes from honey bee pollination (Free, 1993). In addition, the proportions of agricultural crops that depend on honey bee are increasing because of their versatility, low cost, and the ease with which they are moved and managed. Multiple pressures threaten pollinator populations and the pollination services they provide, including the negative effects of insecticides. Bees provide pollination services to various food crops as well as wild plants (Delaplane and Mayer, 2010). Recently, decline in various pollinators have been reported worldwide (Potts et al., 2010; Cameron et al., 2011). Although many environmental and anthropogenic factors remain under investigation for their role in annual honey bee colony losses, pesticides is a major factor (Smith et al., 2014).

Helicoverpa armigera (Hubner) is most destructive pests of field crops worldwide. Its wide dissemination high mobility, survival rate under adverse conditions, capacity to complete several generations in a year (polyvoltine), ability to develop resistance against insecticides, its polyphagy, its ability to undergo facultative diapauses and migration has made its management very difficult (Kumar et al., 2012a).

Pigeon pea is being ravaged by several insect pests, of which the damage caused by the pod borer, Helicoverpa armigera (Hubner) is immensely attributed to greater yield losses and increased cost on crop protection. The severity of pod borer in pigeon pea coincides with the flowering and pod formation of the crop, the activity of honey bees is also characterized as a major contributing factor for yield.

The study of pesticide repellent activity on the pollinators is vital because of the need to manage the insect pest occurring concurrently. The effects of insecticide on honey bees includes direct mortality, sublethal effects, repellent effects and toxicity of the residues present on the floral parts and nectar of the crop plant (Desneux et al., 2007). The repellent effects of insecticides on honey bees have already been reported by many workers in the past on different crops (Thompson and Wilkins, 2003 and Abrol and Kumar, 2009).

In pigeon pea, flowers are yellow with red to reddish-brown. The flowers are selfcompatible and usually self-pollinated. However, there is a good amount of cross pollination which occurs with insect visitations (Saxena et al., 1990). In redgram, honey bees are the major pollination contributors and the peak foraging activity of honey bees in pigeon pea is between 10.00 to $14.00 \mathrm{~h}$ and the major pollinators are Apis florea, Apis cerana and Apis dorsata (Kambrekar et al., 2019). Since, the foraging is during 10.00 to $14.00 \mathrm{~h}$, there is a greater relevance of study of repellent properties of recommended insecticides on honey bees.

During the course of application of insecticides, honey bee directly come in contact with the insecticides or the insecticide treated floral parts which affects behaviors such as communication dances, return flights, orientation, and foraging efficacy during visits to flower (Vandame et al., 1995). Pesticides also known to reduce the ability of honey bees in gathering food from plant and also have lethal effects on the bees. There are two insecticides commonly used by the farmers namely neonicotinoids and organo phosphorous which could affect bees' brains. Studies also indicate that bees fed on neonicotinoid contaminated pollen and nectar produces fewer offspring. On the other hand, certain pesticides can destroy cells in the gut, brain, other tissues, thus affecting the bee's physiology and behavior. Pesticides have been reported to affect the reproductive potential of the bees by reducing sperm viability in drones that causes poor mating and destruction of ovary activation in the developing queen (Tosi et al., 2017). 
Both in response to threats to honeybees and in recognition of the potential benefits of augmenting honey bees, methods are being developed to conserve native and domesticated bee populations. One such strategy involves spraying of insecticides after or before the peak foraging activity of the pollinators including managing agricultural field edges to increase the diversity of floral provisioning resources (Winfree et al., 2008; Egan and Mortensen, 2012) and the abundance of specific floral hosts (Isaacs et al., 2009).

It has been analyzed that decline of honeybee population is due to insecticides like organochlorine, carbamate, organophosphorus and pyrethroid. The damage to honey bee colony by application of pesticides not only depends by toxicity of chemical substances, number and methods of insecticides application, time of application, weather, but also by type of nectar, type of food flower collected, season of damage, number of honeybees in colony and also the type of insecticides used to control the insect pests co-exists.

The purpose of the present investigation was to assess the detrimental effects of insecticides targeted for the management of pod borer in pigeon pea on honey bees under field condition. For this purpose, the repellent activity of the insecticides on honey bees was assessed after being applied on the crop and the activity of the bees was regularly monitored and the recovery of the bees was studied in pigeon pea ecosystem.

\section{Materials and methods}

\section{Study area}

Investigation on repellent activity of insecticides on pollinators of pigeon pea was carried out at two locations viz., Vijayapur and Bagalkot districts of Karnataka (India) during kharif 2018 and 2019. Karnataka is the eighth largest state in India with an area of 190 lakh ha. It is situated between $11.5^{\circ}$ and $19.0^{\circ} \mathrm{N}$ latitude and between $74^{\circ}$ and $78^{\circ} \mathrm{E}$ longitude in the southern plateau. The State receives an average annual rainfall of about $1139 \mathrm{~mm}$ both from southwest and north-east monsoons. Vijyapur district is situated well in the interior of the Deccan Peninsula and lies between north latitude $15^{\circ}$ $20^{\prime}$ and $17^{\circ} 28^{\prime}$. The average annual rainfall of the district is $668.2 \mathrm{~mm}$, the temperature ranges from 14.8 to $43{ }^{\circ} \mathrm{C}$. The climate of the district is generally dry. Bagalkot is located in Northern Dry Zone (Zone-3) of Karnataka. The centre is located at $75^{\circ} 42^{\prime}$ East longitude and $16^{\circ} 10$, North latitude with an altitude of $542.00 \mathrm{~m}$ above Mean Sea Level (MSL). The average annual temperature is $25.8^{\circ} \mathrm{C}$ in Bagalkot. The rainfall here averages $683 \mathrm{~mm}$. The crop was sown at $90 \mathrm{~cm}$ of row spacing and $30 \mathrm{~cm}$ of plant to plant spacing. The crop flowering starts at 70 days after sowing. The first spray was given at 75 days after sowing followed by next two sprays at an interval of 10 days apart. The crops flowers for 30-35 days with staggered flowering.

\section{Insecticides for the management of pod borer, Helicoverpa armigera in pigeon pea}

The spraying of insecticides was done, commensuration to the incidence of pod borer. In each treatment 0.5 ac land was used to know the impact of insecticides on honey bees. Spraying of recommended insecticides was done between 14.00 to $18.00 \mathrm{~h}$ of the day to avoid the peak foraging activity of the honey bees. The spraying was carried out with the help of knapsack sprayer with total volume of spray being $500 \mathrm{~L} / \mathrm{ha}$. 


\begin{tabular}{c|c|c|c|c}
\hline Sl. No. & Insecticide & Group & Mode of action & Dose (ml/g/l) \\
\hline 1 & Thiodicarb 75 WP & Carbamate & Inhibit acetylcholine esterase & 1.00 \\
\hline 2 & NSKE (\%) & Botanical & Feeding deterrent & 5.00 \\
\hline 3 & Chlorantraniliprole 18.5 SC & $\begin{array}{c}\text { Anthranilic } \\
\text { diamide }\end{array}$ & Ryanodine receptor activator & 0.15 \\
\hline 4 & Indoxacarb 14.5 SC & Oxadiazine & $\begin{array}{c}\text { Blocks the neuronal sodium } \\
\text { channels }\end{array}$ & 0.30 \\
\hline 5 & Emamectin benzoate 5\% SG & Abamectin & $\begin{array}{c}\text { GABA - and glutamate-gated } \\
\text { chloride channel agonist }\end{array}$ & 0.20 \\
\hline 6 & Flubendiamide 480 SC & $\begin{array}{c}\text { Phthalic acid } \\
\text { diamide }\end{array}$ & Ryanodine receptor activator & 0.075 \\
\hline
\end{tabular}

\section{Repellent property of the insecticides}

The observation on pollinator visitation was initiated during $10 \%$ flowering till its complete cessation. Observations were made for different species of honey bees visiting the field during flowering at regular interval of time for $5 \mathrm{~min}$ in a square meter area from five spots. The observation on bee visitation was made before the initiation of spray and after the spray of insecticides at one to seven days. Totally three sprays were taken up at ten days interval. The bee visitation recorded after the spray of each insecticide at different intervals was further used to calculate the per cent recovery of the honey bees in comparison with the bee visitation recorded before the spray.

\section{Statistical analysis}

The number of bee visits at different intervals after each spray was assessed and the per cent recovery of bees in the sprayed plots were done in correspondence to the pre count of honey bees before spraying. The transformation values were subjected to ANOVA (Analysis of Variance) (Panse and Sukhatme, 1954) and DMRT (Duncan's Multiple Range Test) by using SAS 9.1 (Statistical Analysis Software) programme.

\section{Results}

The pooled results on the investigation on the effect of insecticides on the foraging activity of different honey bee species as influenced by their visitation after the spraying is herewith presented in Tables 1-3. The average data of two years and two locations is presented.

\section{Apis florea}

Before the spray, the population of A. florea in different plots ranged between 58.50 to 62.50 bees per square meter area during $5 \mathrm{~min}$. The effect of different insecticides on the foraging activity of Apis florea after the spraying revealed statistical difference among the treatments in the restoration of A. florea. Bee restoration varied between 7.93 to $81.08 \%$ on the $1^{\text {st }}$ day after spraying. Neem Seed Kernel Extract (hereafter NSKE) @ $5 \%$ recorded highest restoration bees to the extent of $81.08 \%$ indicating its safety and less repellent activity against $A$. florea. Chlorantraniliprole has recorded $42.61 \%$ recovery of $A$. florea which is the next safe insecticides to A. florea. 
Response of $A$. florea to different insecticides over intervals of post treatment indicated that among the insecticides, normal bee activity (100\% restoration) was realized in the plots treated with NSKE (@5\%) on the $3^{\text {rd }}$ day after the spraying followed by chlorantraniliprole on the $4^{\text {th }}$ day after the spraying. However, in untreated check, normal activity of bee was realized throughout the internals (Table 1).

Table 1. Impact of different insecticides on the activity of Apis florea Fabricius on pigeon pea

\begin{tabular}{|c|c|c|c|c|c|c|c|c|c|c|}
\hline \multirow{2}{*}{ SI. No } & \multirow{2}{*}{ Treatments } & \multirow{2}{*}{$\begin{array}{c}\begin{array}{c}\text { Dose } \\
(\mathrm{ml} / \mathrm{g} / \mathrm{l})\end{array} \\
\end{array}$} & \multirow{2}{*}{$\begin{array}{c}\text { Bees } / \mathbf{m}^{2} / 5 \mathrm{~m} \\
\text { DBS } \\
\end{array}$} & \multicolumn{7}{|c|}{ Per cent recovery of bees after spraying } \\
\hline & & & & 1DAS & 2DAS & 3DAS & 4DAS & 5DAS & 6DAS & 7DAS \\
\hline 1 & Thiodicarb $75 \mathrm{WP}$ & 1.00 & 62.50 & $\begin{array}{c}08.01 \\
(16.43)\end{array}$ & $\begin{array}{c}16.54 \\
(23.99)\end{array}$ & $\begin{array}{c}23.30 \\
(28.85)\end{array}$ & $\begin{array}{c}51.5 \\
(45.89)\end{array}$ & $\begin{array}{c}70.93 \\
(57.35)\end{array}$ & \begin{tabular}{c|}
92.41 \\
$(73.98)$
\end{tabular} & $\begin{array}{l}100.00 \\
(90.00)\end{array}$ \\
\hline 2 & $\operatorname{NSKE}(\%)$ & 5.00 & 60.50 & $\begin{array}{c}81.08 \\
(64.19) \\
\end{array}$ & $\begin{array}{c}95.50 \\
(77.72) \\
\end{array}$ & \begin{tabular}{|l|}
100.00 \\
$(90.00)$ \\
\end{tabular} & $\begin{array}{l}100.00 \\
(90.00) \\
\end{array}$ & $\begin{array}{c}98.92 \\
(84.00) \\
\end{array}$ & \begin{tabular}{c|}
98.92 \\
$(84.00)$ \\
\end{tabular} & $\begin{array}{c}99.47 \\
(85.79) \\
\end{array}$ \\
\hline 3 & Chlorantraniliprole $18.5 \mathrm{SC}$ & 0.15 & 59.50 & $\begin{array}{c}42.61 \\
(40.73) \\
\end{array}$ & $\begin{array}{c}70.34 \\
(56.98) \\
\end{array}$ & \begin{tabular}{|c|}
87.43 \\
$(69.21)$ \\
\end{tabular} & $\begin{array}{l}100.00 \\
(90.00) \\
\end{array}$ & \begin{tabular}{|l|l}
100.00 \\
$(90.00)$ \\
\end{tabular} & \begin{tabular}{|c|}
98.92 \\
$(84.00)$ \\
\end{tabular} & $\begin{array}{c}99.12 \\
(84.58) \\
\end{array}$ \\
\hline 4 & Indoxacarb 14.5 SC & 0.30 & 60.50 & $\begin{array}{c}08.27 \\
(16.71) \\
\end{array}$ & $\begin{array}{c}23.32 \\
(28.86) \\
\end{array}$ & \begin{tabular}{c|}
32.69 \\
$(34.86)$ \\
\end{tabular} & $\begin{array}{c}50.10 \\
(45.04) \\
\end{array}$ & $\begin{array}{c}72.14 \\
(58.12) \\
\end{array}$ & \begin{tabular}{c|}
88.84 \\
$(70.46)$ \\
\end{tabular} & $\begin{array}{c}91.98 \\
(73.52) \\
\end{array}$ \\
\hline 5 & Emamectin benzoate $5 \% \mathrm{SG}$ & 0.20 & 59.50 & $\begin{array}{c}14.53 \\
(22.40) \\
\end{array}$ & $\begin{array}{c}28.02 \\
(31.95) \\
\end{array}$ & \begin{tabular}{c|}
76.32 \\
$(60.86)$ \\
\end{tabular} & $\begin{array}{c}89.54 \\
(71.10) \\
\end{array}$ & $\begin{array}{c}89.89 \\
(71.43) \\
\end{array}$ & \begin{tabular}{|c|}
87.92 \\
$(69.63)$ \\
\end{tabular} & $\begin{array}{c}91.29 \\
(72.81) \\
\end{array}$ \\
\hline 6 & Flubendiamide $480 \mathrm{SC}$ & 0.075 & 58.50 & $\begin{array}{c}07.93 \\
(16.35) \\
\end{array}$ & $\begin{array}{c}25.28 \\
(30.17) \\
\end{array}$ & \begin{tabular}{|c|}
43.67 \\
$(41.35)$ \\
\end{tabular} & $\begin{array}{c}75.34 \\
(60.20) \\
\end{array}$ & $\begin{array}{c}92.68 \\
(74.27) \\
\end{array}$ & \begin{tabular}{|c|}
89.81 \\
$(71.36)$ \\
\end{tabular} & $\begin{array}{c}75.92 \\
(60.59) \\
\end{array}$ \\
\hline 7 & Untreated check & - & 60.50 & $\begin{array}{l}100.00 \\
(90.00) \\
\end{array}$ & $\begin{array}{l}100.00 \\
(90.00) \\
\end{array}$ & $\begin{array}{l}100.00 \\
(90.00) \\
\end{array}$ & $\begin{array}{l}100.00 \\
(90.00) \\
\end{array}$ & $\begin{array}{c}99.28 \\
(85.10) \\
\end{array}$ & \begin{tabular}{c|}
99.47 \\
$(85.79)$ \\
\end{tabular} & $\begin{array}{c}98.67 \\
(83.34) \\
\end{array}$ \\
\hline & S.Em \pm & - & - & 2.77 & 3.09 & 3.28 & 2.39 & 3.26 & 3.60 & 4.24 \\
\hline & $\mathrm{CD}(\mathrm{P}=0.05)$ & - & NS & 8.55 & 9.39 & 10.07 & 7.37 & 10.06 & 10.94 & 12.91 \\
\hline & $\mathrm{CV}$ & - & - & 10.56 & 12.43 & 10.96 & 10.85 & 10.72 & 9.58 & 10.72 \\
\hline
\end{tabular}

DBS: Day before spraying, DAS: Days after spraying. Figures in the parenthesis are arcsine transformed values. Bees $/ \mathrm{m}^{2} / 5 \mathrm{~m}$ : Number of bees per square meter area per 5 min

Emamectin benzoate recorded slow and steady visitation by bees after the spraying wherein at the $7^{\text {th }}$ day after spraying $91.29 \%$ recovery was recorded indicting the persistent repellency over a long period of time. Similarly, thiodicarb and indoxacarb recorded lowest recovery of the bees up to $3^{\text {rd }}$ day after the spray and the recovery gradually increased towards $7^{\text {th }}$ day and allowed almost normal bee activity on the $7^{\text {th }}$ day indicating their acute repellency up to $3^{\text {rd }}$ day of the spraying.

\section{Apis cerana indica}

The normal foraging activity of $A$. ceran before spraying was 48.50 to 52.50 bees per square meter area during $5 \mathrm{~min}$. The repellent effect of different insecticides on the recovery of Apis cerana after the spraying indicate Neem Seed Kernel Extract with higher bee activity (77.76\%). Emamectin benzoate and chlorantraniliprole have recorded 50.14 and $41.61 \%$ recovery of $A$. cerana and are the next safe insecticides to A. cerana. Indoxacarb was the most toxic insecticide where only $2.39 \%$ and $7.24 \%$ bees returned back to the treated plot on $1^{\text {st }}$ and $2^{\text {nd }}$ day after the spray. The normal activity of the bees was assumed on $3^{\text {rd }}, 4^{\text {th }}$ and $5^{\text {th }}$ day after spray in the plots sprayed with NSKE, chlorantraniliprole and flubendiamide respectively (Table 2). This indicates the diverse response of $A$. cerana indica to the insecticides used for the management of the pod borer in pigeon pea. 
Table 2. Impact of different insecticides on the activity of Apis cerena Fabricius on pigeon pea

\begin{tabular}{|c|c|c|c|c|c|c|c|c|c|c|}
\hline \multirow{2}{*}{ Sl. No } & \multirow{2}{*}{ Treatments } & \multirow{2}{*}{$\begin{array}{c}\text { Dose } \\
(\mathbf{m l} / \mathrm{g} / \mathbf{l})\end{array}$} & \multirow{2}{*}{$\begin{array}{c}\text { Bees } / \mathbf{m}^{2} / 5 m \\
\text { DBS }\end{array}$} & \multicolumn{7}{|c|}{ Per cent recovery of bees after spraying } \\
\hline & & & & 1DAS & 2DAS & 3DAS & 4DAS & 5DAS & 6DAS & 7DAS \\
\hline 1 & Thiodicarb $75 \mathrm{WP}$ & 1.00 & 52.00 & $\begin{array}{c}10.81 \\
(19.19)\end{array}$ & $\begin{array}{c}21.67 \\
(27.73)\end{array}$ & $\begin{array}{c}56.01 \\
(48.43)\end{array}$ & $\begin{array}{c}76.06 \\
(60.68)\end{array}$ & $\begin{array}{c}91.84 \\
(73.46)\end{array}$ & $\begin{array}{c}96.27 \\
(78.91)\end{array}$ & $\begin{array}{c}87.14 \\
(68.95)\end{array}$ \\
\hline 2 & $\operatorname{NSKE}(\%)$ & 5.00 & 49.50 & $\begin{array}{c}77.76 \\
(61.84)\end{array}$ & $\begin{array}{c}91.06 \\
(72.57)\end{array}$ & $\begin{array}{c}98.78 \\
(83.62)\end{array}$ & $\begin{array}{l}100.00 \\
(90.00)\end{array}$ & $\begin{array}{c}97.57 \\
(81.09)\end{array}$ & $\begin{array}{l}100.00 \\
(90.00)\end{array}$ & $\begin{array}{l}100.00 \\
(90.00)\end{array}$ \\
\hline 3 & Chlorantraniliprole $18.5 \mathrm{SC}$ & 0.15 & 50.50 & $\begin{array}{c}41.61 \\
(40.15)\end{array}$ & $\begin{array}{c}87.33 \\
(69.12)\end{array}$ & $\begin{array}{c}95.27 \\
(77.41)\end{array}$ & $\begin{array}{l}100.00 \\
(90.00)\end{array}$ & $\begin{array}{c}97.22 \\
(80.37)\end{array}$ & $\begin{array}{c}94.78 \\
(76.83)\end{array}$ & $\begin{array}{l}100.00 \\
(90.00)\end{array}$ \\
\hline 4 & Indoxacarb $14.5 \mathrm{SC}$ & 0.30 & 52.00 & $\begin{array}{l}02.39 \\
(8.89) \\
\end{array}$ & $\begin{array}{c}7.24 \\
(15.60) \\
\end{array}$ & $\begin{array}{c}38.52 \\
(38.35) \\
\end{array}$ & \begin{tabular}{|c|}
53.77 \\
$(47.14)$ \\
\end{tabular} & $\begin{array}{c}85.33 \\
(67.45)\end{array}$ & $\begin{array}{l}100.00 \\
(90.00)\end{array}$ & $\begin{array}{c}89.76 \\
(71.37)\end{array}$ \\
\hline 5 & Emamectin benzoate $5 \% \mathrm{SG}$ & 0.20 & 52.50 & $\begin{array}{c}50.14 \\
(45.06) \\
\end{array}$ & $\begin{array}{c}70.98 \\
(57.38) \\
\end{array}$ & $\begin{array}{c}79.02 \\
(62.71) \\
\end{array}$ & $\begin{array}{c}85.33 \\
(67.45) \\
\end{array}$ & $\begin{array}{c}80.37 \\
(63.72) \\
\end{array}$ & \begin{tabular}{|c|}
73.80 \\
$(59.21)$ \\
\end{tabular} & $\begin{array}{c}49.87 \\
(44.89) \\
\end{array}$ \\
\hline 6 & Flubendiamide $480 \mathrm{SC}$ & 0.075 & 49.00 & $\begin{array}{c}10.76 \\
(19.14)\end{array}$ & $\begin{array}{c}35.34 \\
(36.46)\end{array}$ & $\begin{array}{c}58.51 \\
(49.88)\end{array}$ & $\begin{array}{c}96.32 \\
(78.91)\end{array}$ & $\begin{array}{l}100.00 \\
(90.00)\end{array}$ & $\begin{array}{c}86.32 \\
(68.28)\end{array}$ & $\begin{array}{c}96.42 \\
(79.06)\end{array}$ \\
\hline 7 & Untreated check & - & 48.50 & $\begin{array}{l}100.00 \\
(90.00)\end{array}$ & $\begin{array}{l}100.00 \\
(90.00)\end{array}$ & $\begin{array}{l}100.00 \\
(90.00)\end{array}$ & $\begin{array}{l}100.00 \\
(90.00)\end{array}$ & $\begin{array}{c}98.26 \\
(82.51)\end{array}$ & $\begin{array}{c}96.69 \\
(79.53)\end{array}$ & $\begin{array}{c}99.43 \\
(85.67)\end{array}$ \\
\hline & S.Em \pm & - & - & 3.27 & 3.66 & 3.51 & 3.39 & 3.26 & 3.60 & 4.24 \\
\hline & $\mathrm{CD}(\mathrm{P}=0.05)$ & - & NS & 10.09 & 11.29 & 10.82 & 10.45 & 10.06 & 10.94 & 12.91 \\
\hline & $\mathrm{CV}$ & - & - & 11.93 & 11.54 & 9.60 & 10.14 & 10.72 & 9.58 & 10.72 \\
\hline
\end{tabular}

DBS: Day before spraying DAS: Days after spraying. Figures in the parenthesis are arcsine transformed values. Bees $/ \mathrm{m}^{2} / 5 \mathrm{~m}$ : Number of bees per square meter area per $5 \mathrm{~min}$

\section{Apis dorsata}

Before spraying, the total number of $A$. dorsata bees in all the experimental plots ranged from 21.00 to 23.00 bees per square meter area for $5 \mathrm{~min}$ and was significantly less compared to A. cerana and A. florea indicating the less contribution by A. dorsata in pigeon pea pollination. However, the response of Apis dorsata to different insecticides in pigeon pea revealed variation compared to the other two species of honey bees. NSKE and chlorantraniliprole have recorded $100 \%$ recovery of the bees on the very second day of the spray indicating the quick resumption of A. dorsata. Further, A. dorsata responded differently to indoxacarb, flubendiamide and Thiodicarb wherein there was a gradual increase in the foraging activity of bees over days after spraying. Interestingly emamectin benzoate encouraged bees better up to 4 days of spray and thereafter there was a decline in the foraging as indicated by reduced recovery of bees on towards 6 and 7 days after spray with 57.78 and $59.70 \%$ respectively (Table 3).

The mean of all the intervals is calculated and there was a clear indication that NSKE and chlorantraniliprole encouraged all the three species of honey bees to come back to the farm. NSKE recorded an average of 96.34 and $88.52 \%$ recovery irrespective of the interval and the honey bee species. As per the present investigation, indoxacarb and thiodicarb were the insecticides with more repellent activity to the bees. The categorization of insecticides with the increased repellent activity to A. florea is NSKE $>$ chlorantraniliprole $>$ emamectin benzoate $>$ flubendiamide $>$ indoxacarb $>$ thiodicarb, whereas, against A. cerana the repellent activity is in the hierarchy of NSKE > chlorantraniliprole $>$ emamectin benzoate $>$ flubendiamide $>$ thiodicarb $>$ indoxacarb. Further, against $A$. dorsata the repellent activity of the insecticides in the increasing order is NSKE > chlorantraniliprole > flubendiamide > emamectin benzoate > thiodicarb > indoxacarb (Table 4; Fig. 1). 
Table 3. Impact of different insecticides on the activity of Apis dorsata Fabricius on pigeon pea

\begin{tabular}{|c|c|c|c|c|c|c|c|c|c|c|}
\hline \multirow{2}{*}{ SI. No } & \multirow{2}{*}{ Treatments } & \multirow{2}{*}{$\begin{array}{c}\text { Dose } \\
(\mathrm{ml} / \mathrm{g} / \mathrm{l})\end{array}$} & \multirow{2}{*}{$\begin{array}{c}\text { Bees } / \mathbf{m}^{2} / 5 \text { m } \\
\text { DBS }\end{array}$} & \multicolumn{7}{|c|}{ Per cent recovery of bees after spraying } \\
\hline & & & & 1DAS & 2DAS & 3DAS & 4DAS & 5DAS & 6DAS & 7DAS \\
\hline 1 & Thiodicarb $75 \mathrm{WP}$ & 1.00 & 21.50 & $\begin{array}{c}17.09 \\
(24.41)\end{array}$ & $\begin{array}{c}37.87 \\
(37.96)\end{array}$ & $\begin{array}{c}68.11 \\
(55.60)\end{array}$ & $\begin{array}{c}87.96 \\
(69.67)\end{array}$ & $\begin{array}{c}91.90 \\
(73.44)\end{array}$ & \begin{tabular}{|c|}
90.85 \\
$(72.36)$
\end{tabular} & $\begin{array}{c}86.78 \\
(68.65)\end{array}$ \\
\hline 2 & $\operatorname{NSKE}(\%)$ & 5.00 & 22.00 & $\begin{array}{c}87.51 \\
(69.28) \\
\end{array}$ & $\begin{array}{l}100.00 \\
(90.00)\end{array}$ & $\begin{array}{l}100.00 \\
(90.00)\end{array}$ & $\begin{array}{l}100.00 \\
(90.00)\end{array}$ & $\begin{array}{c}97.99 \\
(81.82)\end{array}$ & \begin{tabular}{|c|}
98.74 \\
$(83.52)$
\end{tabular} & \begin{tabular}{|l|}
100.00 \\
$(90.00)$
\end{tabular} \\
\hline 3 & Chlorantraniliprole $18.5 \mathrm{SC}$ & 0.15 & 22.50 & $\begin{array}{c}54.47 \\
(47.55)\end{array}$ & $\begin{array}{l}100.00 \\
(90.00)\end{array}$ & $\begin{array}{c}100.00 \\
(90.00)\end{array}$ & $\begin{array}{l}100.00 \\
(90.00)\end{array}$ & $\begin{array}{c}98.13 \\
(82.11)\end{array}$ & $\begin{array}{l}100.00 \\
(90.00)\end{array}$ & $\begin{array}{c}91.31 \\
(72.83)\end{array}$ \\
\hline 4 & Indoxacarb $14.5 \mathrm{SC}$ & 0.30 & 23.00 & $\begin{array}{c}6.37 \\
(14.61) \\
\end{array}$ & $\begin{array}{c}26.31 \\
(30.85) \\
\end{array}$ & $\begin{array}{c}52.74 \\
(46.55) \\
\end{array}$ & $\begin{array}{c}85.50 \\
(67.59) \\
\end{array}$ & $\begin{array}{c}95.40 \\
(77.58) \\
\end{array}$ & \begin{tabular}{|c|}
88.49 \\
$(70.14)$ \\
\end{tabular} & \begin{tabular}{|l|}
100.00 \\
$(90.00)$ \\
\end{tabular} \\
\hline 5 & Emamectin benzoate $5 \% \mathrm{SG}$ & 0.20 & 21.00 & $\begin{array}{c}34.60 \\
(36.02)\end{array}$ & $\begin{array}{c}80.15 \\
(63.52)\end{array}$ & $\begin{array}{c}96.79 \\
(79.65)\end{array}$ & $\begin{array}{l}100.00 \\
(90.00)\end{array}$ & $\begin{array}{c}74.68 \\
(59.76)\end{array}$ & $\begin{array}{c}57.78 \\
(49.46)\end{array}$ & \begin{tabular}{|c}
59.70 \\
$(50.57)$
\end{tabular} \\
\hline 6 & Flubendiamide $480 \mathrm{SC}$ & 0.075 & 23.00 & $\begin{array}{c}35.76 \\
(36.71) \\
\end{array}$ & $\begin{array}{c}61.01 \\
(51.34) \\
\end{array}$ & $\begin{array}{c}82.49 \\
(65.24) \\
\end{array}$ & \begin{tabular}{c|}
96.31 \\
$(78.89)$ \\
\end{tabular} & $\begin{array}{l}100.00 \\
(90.00) \\
\end{array}$ & \begin{tabular}{|c|}
96.23 \\
$(78.77)$ \\
\end{tabular} & \begin{tabular}{|l|}
100.00 \\
$(90.00)$ \\
\end{tabular} \\
\hline \multirow[t]{4}{*}{7} & Untreated check & - & 22.00 & $\begin{array}{c}99.62 \\
(86.43)\end{array}$ & $\begin{array}{c}96.50 \\
(79.19)\end{array}$ & $\begin{array}{c}100.00 \\
(90.00)\end{array}$ & $\begin{array}{c}100.00 \\
(90.00)\end{array}$ & $\begin{array}{c}92.75 \\
(74.35)\end{array}$ & $\begin{array}{c}99.62 \\
(86.43)\end{array}$ & \begin{tabular}{|c}
77.71 \\
$(61.80)$
\end{tabular} \\
\hline & S.Em \pm & - & & 3.32 & 3.69 & 3.47 & 3.42 & 3.90 & 3.51 & 3.42 \\
\hline & $\mathrm{CD}(\mathrm{P}=0.05)$ & - & & 10.09 & 11.38 & 11.01 & 10.40 & 11.70 & 10.68 & 10.54 \\
\hline & $\mathrm{CV}$ & - & & 9.18 & 9.74 & 10.16 & 9.81 & 12.61 & 10.66 & 11.58 \\
\hline
\end{tabular}

DBS: Day before spraying DAS: Days after spraying. Figures in the parenthesis are arcsine transformed values. Bees $/ \mathrm{m}^{2} / 5 \mathrm{~m}$ : Number of bees per square meter area per $5 \mathrm{~min}$

Table 4. Impact of different insecticides on the activity of different species of honey bees in pigeon pea (Mean of all the intervals)

\begin{tabular}{c|c|c|c|c|c|c}
\hline \multirow{2}{*}{ Sl. No } & Treatments & \multirow{2}{*}{$\begin{array}{c}\text { Dose } \\
(\mathbf{m l} / \mathbf{g} / \mathbf{l})\end{array}$} & \multicolumn{2}{|c|}{$\begin{array}{c}\text { Average per cent recovery of different } \\
\text { species of bees after spraying }\end{array}$} & \multirow{2}{*}{ Average } \\
\cline { 4 - 5 } & & & A. florea & A. cerana & A. dorsata & \\
\hline 1 & Thiodicarb 75 WP & 1.00 & 51.82 & 61.127 & 68.65 & 60.53 \\
2 & NSKE (\%) & 5.00 & 96.27 & 94.987 & 97.75 & 96.34 \\
3 & Chlorantraniliprole 18.5 SC & 0.15 & 85.49 & 88.893 & 91.18 & 88.52 \\
4 & Indoxacarb 14.5 SC & 0.30 & 52.48 & 50.697 & 64.97 & 56.05 \\
5 & Emamectin benzoate 5\% SG & 0.20 & 68.22 & 79.224 & 71.96 & 73.13 \\
6 & Flubendiamide 480 SC & 0.075 & 58.66 & 65.620 & 80.48 & 68.25 \\
7 & Untreated check & - & 99.63 & 99.631 & 95.17 & 98.14 \\
\hline
\end{tabular}

It is evident from the results that NSKE and chlorantraniliprole were safe to all the three species of honey bees with less repellent activity which is envisaged by the quick recovery of bee species. Indoxacarb was with a high repellent activity against $A$. cerana and $A$. dorsata whereas, thiodicarb is more toxic to A. florea. Emamectin benzoate is more toxic to $A$. dorsata compared to A. florea and A. cerana indica. Further, flubendiamide is safer to A. dorsata but toxic to A. florae and A. cerana indica.

\section{Response of honey bee species to different insecticides}

Irrespective of the interval and the insecticides tested, A. dorsata $(81.45 \%)$ recovered very fast to the sprayed field compared to A. cerana ( $77.17 \%$ recovery) and $A$. florea ( $73.22 \%$ recovery). A. florea is the most sensitive species of honey bees in pigeon pea to insecticides (Fig. 2). 


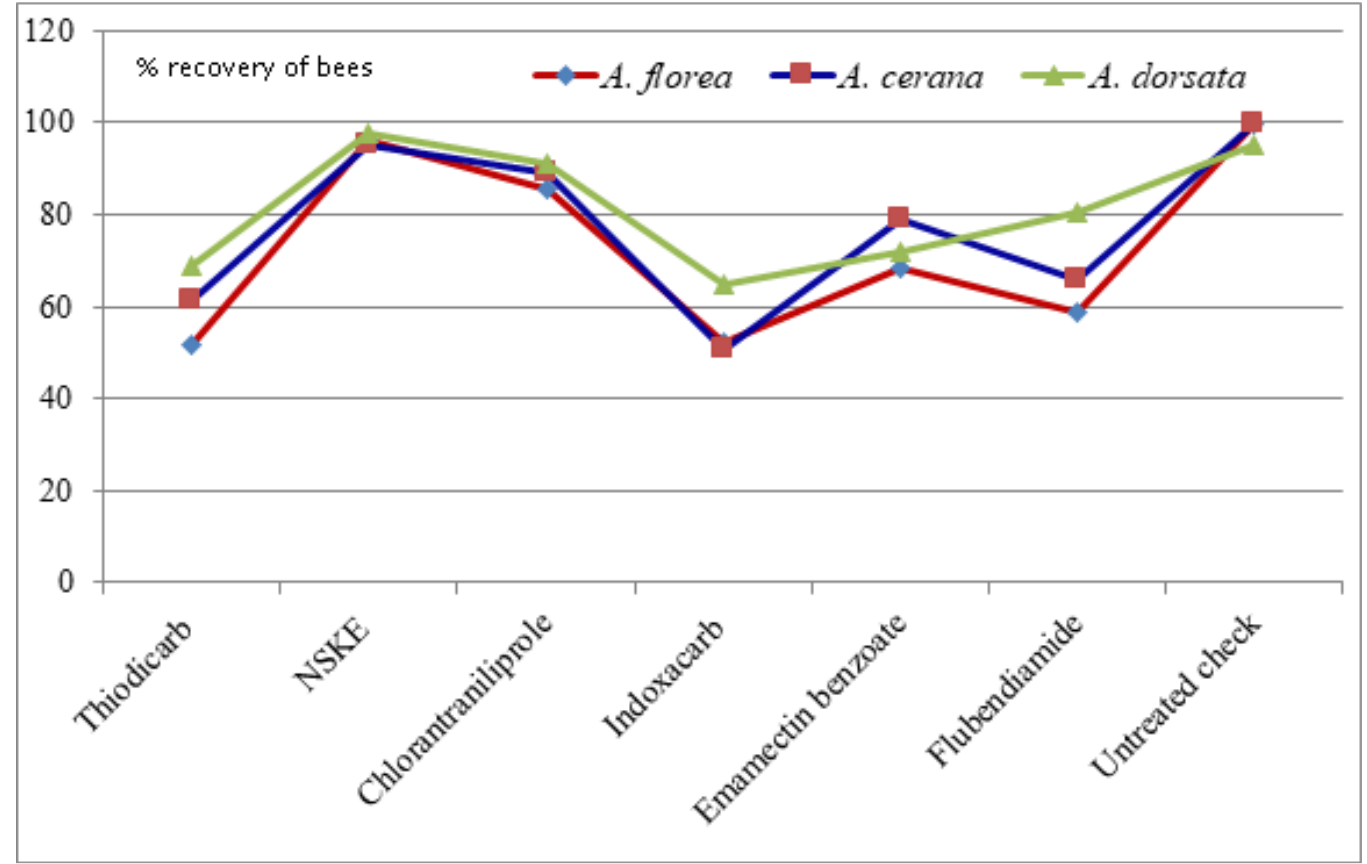

Figure 1. Influence of different insecticides on three species of honey bees in pigeon pea (mean of all intervals)

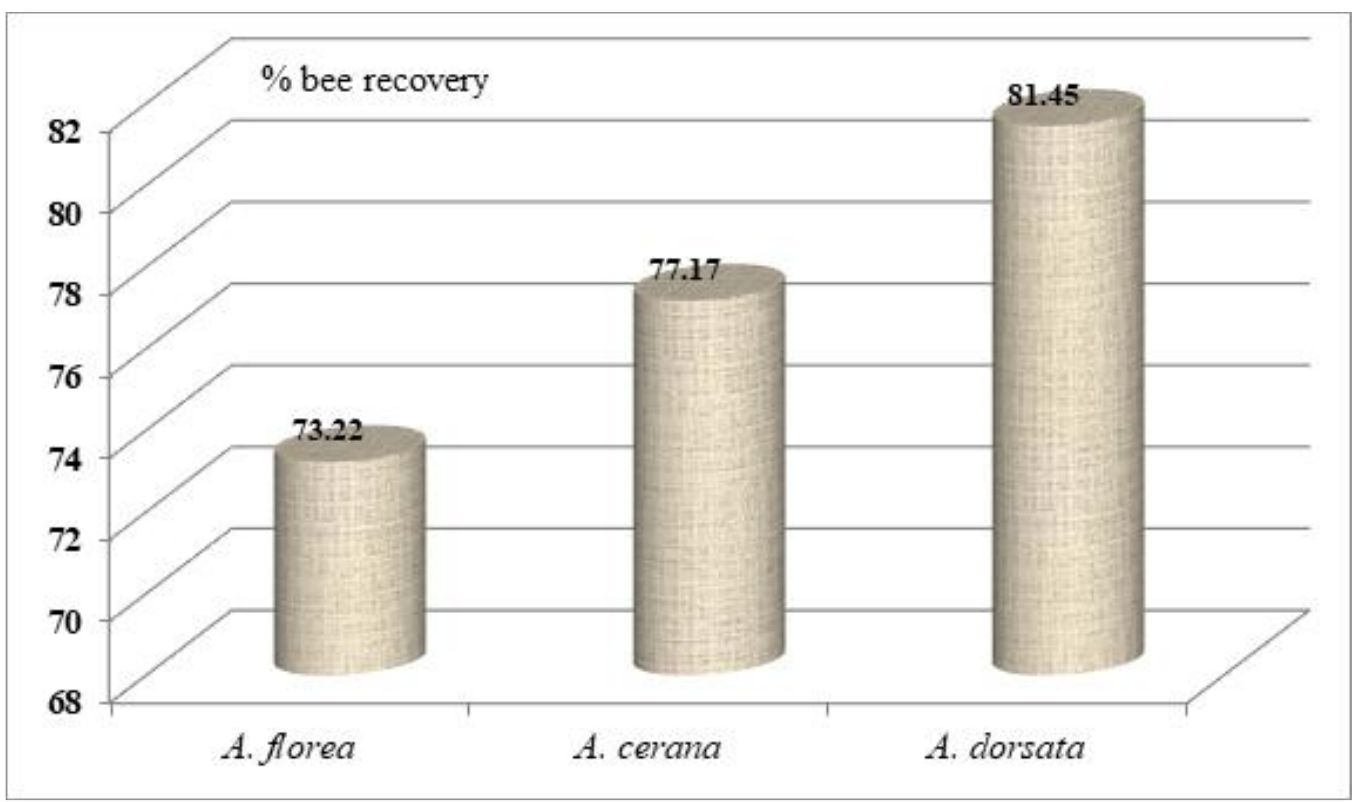

Figure 2. Recovery of different species of honey bees in pigeon pea (mean of all intervals and insecticides)

\section{Repellent activity of insecticides to honey bees}

The analysis was also made to understand the impact of insecticides to honey bee irrespective of the species studied. It is indicative that the neem-based insecticide has recorded almost more than $80 \%$ recovery on the very next day of the spray and attained almost $100 \%$ on the second to third day of spraying and remained safer to all the species 
throughout the week. Chlorantraniliprole has encouraged more than $40 \%$ of the bees and took almost 3 to 4 days to assume the normal activity and thereafter it remained as safe as that of NSKE. Emamectin benzoate and flubendiamide took 4 days to reach the maximum recovery of $90 \%$. Thereafter, the safety of emamectin benzoate declined steadily and reached less than $80 \%$ during 6 and 7 days of the spray. Whereas, in case of flubendiamide, the recovery of bees increased gradually on $6^{\text {th }}$ day and thereafter declined gradually toward $7^{\text {th }}$ day and remained on par with emamectin benzoate at $7^{\text {th }}$ day of the spray (Fig. 3). The increase in the repellent activity of emamectin benzoate after the $4^{\text {th }}$ day is a fact to be investigated keeping its mode of action and release of secondary metabolites on the plan surface which are more toxic than its original ingredient.

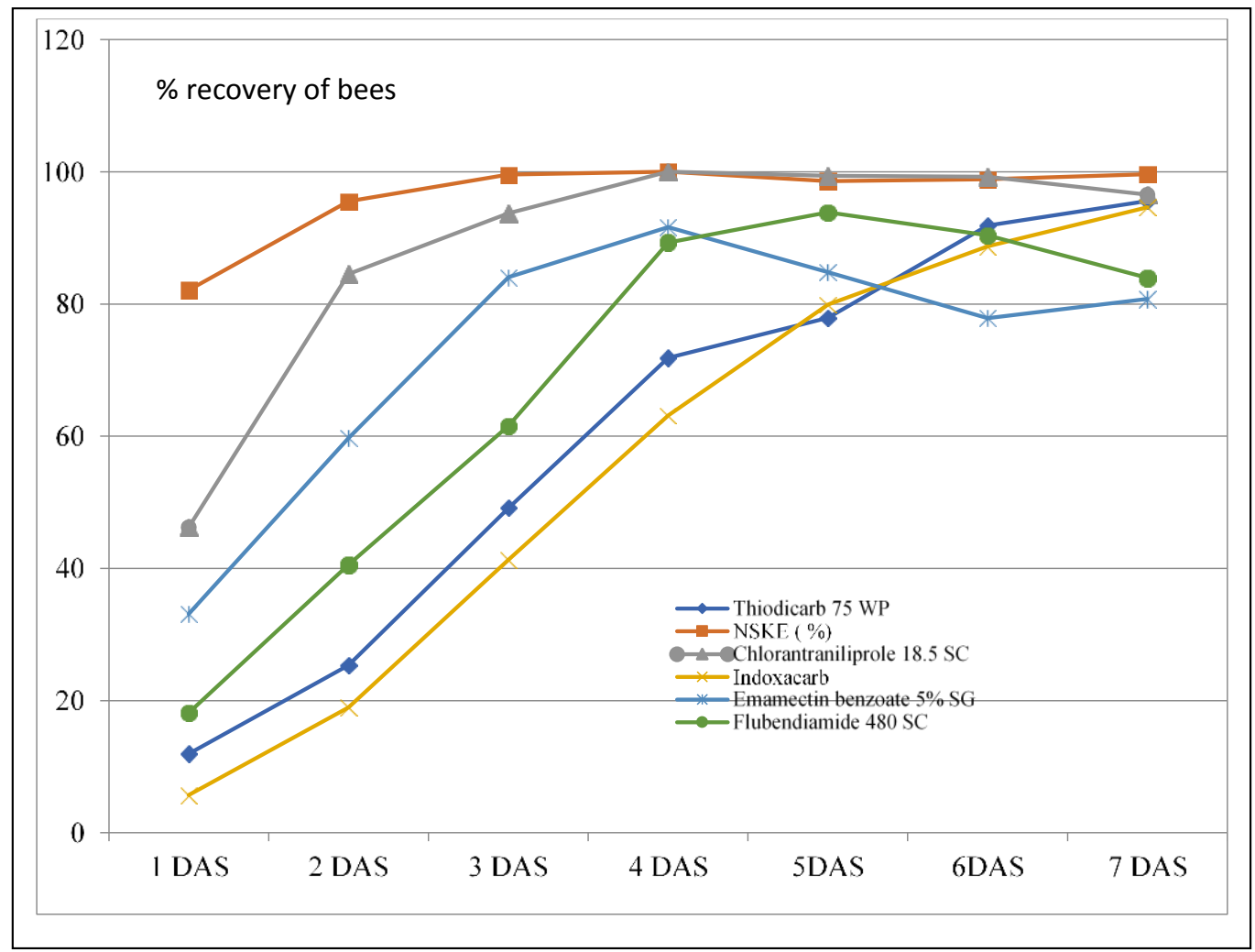

Figure 3. Repellent activity of insecticides to honey bees (mean of three species)

The recovery in case of thiodicarb and indoxacarb is consistent and it gradually increasing towards $5^{\text {th }}$ day of the spray and thereafter there was a varied response. The 2-3 day time to assume the normal foraging activity in NSKE and chlorantraniliprole has a greater relevance in augmenting the bee activity in the treated area where they can contribute immensely towards pollination during the peak flowering period of pigeon pea.

\section{Discussion}

Among the bad effects of insecticides on beneficial insects, sublethal effects imparted by the insecticides have greater significance and thereby gaining more attention in the present-day agriculture (Desneux et al., 2007). Both lethal and sublethal 
effects should be taken into consideration during risk assessments of pesticides on the ecosystem services rendered by the pollinators under filed condition. Although it was documented that neonicotinoid insecticides have contributed to honey bee losses, little has been known about the impact of other group of insecticides on pollinator services under field condition. This study is the first to show the repellent properties of insecticides under field conditions that directly affect the foraging activity of honey bees in pigeon pea ecosystem.

The results recorded on the impact of different insecticides used in the management of $H$. armigera on pollinators of pigeon pea indicated that except untreated control, there was marked reduction in the foraging activity of bees. In our present findings, NSKE and chlorantraniliprole imparted less repellent effect and achieved maximum bee recovery at a faster rate within 2 to 3 days after the spray. There was a sustained repellent effect in case of thiodicarb, indoxacarb and flubendiamide. Kumar et al. (2013) found that neem extracts significantly $(\mathrm{P}<0.0001)$ reduce the Helicoverpa armigera larval population and adult emergence, some adult abnormalities were also recorded from $2.5 \%$ NSE, $2.5 \%$ NLE and $10 \%$ NLE. The results of the present finding on safety of azadirachtin showing fast recovery of bees is in conformity with the findings of Egan and Mortensen (2012) and Kumar et al. (2010), who reported azadirachtin did not deter the honey bees in the field. Similarly, least repellence of neem products was observed by Umrao et al. (2012) and Kumar and Singh (2012), which endorse the results of the present investigations.

In the present findings, chlorantraniliprole treated plots regained the normal bee population within short period which is in accordance with the findings of Jonathan et al. (2013) who observed neither bumble bees nor honey bees avoided foraging on treated white clover in open plots with chlorantraniliprole. Chlorantraniliprole is primarily active on chewing insect pests by ingestion and by contact, showing good larvicidal activity. The remarkably low toxicity combined with low use rates provides large margins of safety for consumers, beneficial insects and with minimal impact on pollinators and beneficial insects (Bassi et al., 2009).

As evidenced in the study, the normal bee activity was on the $2^{\text {nd }}$ after spray in case of Apis dorsata and Apis cerana. Chlorantraniliprole has an excellent profile of safety to beneficial arthropods, pollinators and non-target organisms such as earthworms and soil microorganisms. The product effects on honeybees have been studied extensively, demonstrating low intrinsic toxicity and no negative effects were observed under semifield conditions on foraging honey bees in numerous tunnel tests (Dinter et al., 2008). Further, he also concluded that chlorantraniliprole in addition to its excellent performance in IPM programmes, conserves pollinating honey bees and bumble bees on flowering Phacelia or wheat. In the present findings, emamectin benzoate also showed good recovery of honey bees for 4 days. The inferences of the present results are in line with the findings of Amechi et al. (1997) who reported better colonization of Apis mellifera (L.) and Diglyphusisaea (Walker) on the emamectin benzoate treated crops within relatively short intervals $(\leq 24 \mathrm{~h})$ after applications.

As witnessed in the findings, the population of honey bees showed more variation in their repellent activity against different insecticides. If the spray is scheduled with safe and effective insecticide during peak foraging, that will cause less direct impact on beneficial insects mainly pollinators. Hence, scheduling spraying with the insecticide with low repellent activity has immense significance in augmenting the ecosystem services by pollinators for better yields which in turn conserve the insect pollinators and biodiversity. 
Thus, we propose that significant attention should also be paid on direct exposure of repellent insecticides on honey bees. In conclusion, although there is a variation in the impact of insecticides on honey bees, this study suggested that the insecticides like the NSKE and chlorantraniliprole can restore the honey bees at faster rate and bring the bees back to the farm for effective pollination.

\section{Conclusion}

The present investigation indicates the importance of repellent properties of insecticides concerning honey bees in pigeon pea which elucidates the fastest recovery percentage of honey bees (Apis florea, Apis cerana and Apis dorsata) in the plots treated with Neem Seed Kernel Extract followed by chlorantraniliprole compared to other insecticides. Further, among the bee species studied, A. dorsata resumed its normal activity sooner than A. cerana and A. florea. A. florea was the most sensitive species to insecticides.

Acknowledgement. The authors are grateful to M/s Syngenta India Limited, Pune (India) for the financial assistance to carry out the research under the Operation Pollinators - India project.

\section{REFERENCES}

[1] Abrol, D. P., Kumar, A. (2009): Foraging activity of Apis species on strawberry blossoms as influenced by pesticides. - Pakistan Entomologist 31(1): 57-65.

[2] Amechi, C. C., David, L. C., Susan, J. P., Leslie, A., Morneweck, L. D., Payne, D. M., Dunbar, P. G., Wislocki. (1997): Toxicity of emamectin benzoate foliar dislodgeable residues to two beneficial insects. - Journal of Agricultural and Food Chemistry 45(9): 3689-3693.

[3] Bassi, A., Rison, J. L., Wiles, J. A. (2009): Chlorantraniliprole (DPX-E2Y45, RYNAXYPYR ${ }^{\circledR}$, CORAGEN®), A New Diamide Insecticide for Control of Codling Moth (Cydia pomonella), Colorado Potato Beetle (Leptinotarsa decemlineata) and European Grapevine Moth (Lobesi abotrana). - DuPont, Italy.

[4] Cameron, S. A., Lozier, J. D., Strange, J. P., Koch, J. B., Cordes, N. (2011): Patterns of widespread decline in North American bumble bees. - Proceedings of National Academy Sciences, USA 108: 662-667.

[5] Delaplane, K. S., Mayer, D. F. (2010): Crop Pollination by Bees. - CABI, Wallingford.

[6] Desneux, N., Decourtey, A., Delpuech, J. M. (2007): The sub-lethal effects of pesticides on beneficial arthropods. - Annual Review of Entomology 52: 81-106.

[7] Dinter, A., Brugger, K., Bassi, A., Frost, N. M., Woodward, M. D. (2008): Chlorantraniliprole (DPX-E2Y45, Rynaxypyr $\left.{ }^{\circledR}\right)$ (Coragen ${ }^{\circledR}$ 20SC and Altacor $\left.{ }^{\circledR} 35 \mathrm{WG}\right)$ - a novel DuPont anthranilic diamide insecticide - demonstrating low toxicity and low risk for beneficial insects and predatory mites. - IOBC WPRS Bulletin 35:128-135.

[8] Egan, J. F., Mortensen, D. A. (2012): A comparison of land sharing and land sparing strategies for conserving plant species richness in agricultural landscapes. - Ecological Applications 22(2) 459-461.

[9] Free, J. B. (1993): Insect Pollination of Crops. 2nd Ed. - Harcourt Brace, London.

[10] Isaacs, R. J., Tuell, A., Fiedler, M. G., Landis, D. (2009): Maximizing arthropodmediated ecosystem services in agricultural landscapes: the role of native plants. Frontiers in Ecology and the Environment 7: 196-201. 
[11] Jonathan, L. L., Carl, T. R., Daniel, A. P. (2013): Assessing insecticide hazard to bumble bees foraging on flowering weeds in treated lawns. - PloS ONE 12: 1-5. doi.org/10.1371/journal.pone.0066375.

[12] Kambrekar, D. N., Raikar, M., Jahagirdar, S., Gudadur, K. (2019): Pollinator fauna associated with pigeon pea, Cajanus cajan (L.) Millspaugh in Bijapur and Bagalkot district of Karnataka. - Journal of Entomology and Zoology Studies 7(4): 158-161.

[13] Kumar, A., Singh, R. (2012): Effect of biopesticides and insecticides on aphid population, bee visits and yield of mustard. - Annals of Plant Protection Sciences 20: 205-209.

[14] Kumar, A., Singh, R., Awaneesh, C., Verma, R. A. (2010): Pesticides effect on visit and forage activities of honey bee in mustard (Brassica juncea). - Current Advances in Agricultural Sciences 2(2): 131-132.

[15] Kumar, A., Mishra, M., Prakash, S. (2013): Effects of Neem extracts on metamorphosis of Helicoverpa armigera (Hubner). - Journal of Experimental Zoology India 16(1): 199203.

[16] Panse, V. G., Sukhatme, P. V. (1954): Statistical Methods for Agricultural Workers. ICAR Publication, New Delhi.

[17] Potts S. G., Biesmeijer, J. C., Kremen, C., Neumann, P., Schweiger, O. (2010): Global pollinator declines: trends, impacts and drivers. - Trends in Ecological Evolution 25: 345-353.

[18] Saxena, K. B., Singh, L., Gupta, M. D. (1990): Variation for natural out crossing in pigeon pea. - Euphytica 46143.

[19] Smith, K. M., Loh, E. H., Rostal, M. K., Zambrana-Torrelio, M., Mendiola, L., Daszak, P. (2014): Pathogens, pests, and economics: drivers of honey bee colony declines and losses. - Eco Health. DOI: 10.1007/s10393013-0870-0872.

[20] Thompson, H., Wilkins, S. (2003): Assessment of the synergy and repellency of pyrethroid/fungicide mixtures. - Bulletin of Insectology 56(1): 131-134.

[21] Tosi, S., Burgio, G., Nieh, J. C. (2017): A common neonicotinoid pesticide, thiamethoxam, impairs honey bee flight ability. - Scientific Reports 7.

[22] Umrao, R. S., Pal, R. K., Singh, D. K. (2012): Studies of some insecticides and biopesticides on foraging behaviour of honey bees in mustard (Brassica juncea L.). Asian Journal of Biosciences 7(2): 214-215.

[23] Vandame, R., Meled, M., Colin, M. E., Belzunces, L. P. (1995): Alteration of the homing flight in the bee Apis mellifera L. exposed to sublethal dose of deltamethrin. Environmental Toxicology and Chemistry 14: 855-860.

[24] Winfree, R. N. M., Williams, H., Gaines, J. S., Ascher Kremen, C. (2008): Wild bee pollinators provide the majority of crop visitation across land-use gradients in New Jersey and Pennsylvania, USA. - Journal of Applied Ecology 45(3): 793-802. 